Editorial

\title{
Research in Nickel/Metal Hydride Batteries 2016
}

\author{
Kwo-Hsiung Young ${ }^{1,2}$ \\ 1 BASF/Battery Materials-Ovonic, 2983 Waterview Drive, Rochester Hills, MI 48309, USA; \\ kwo.young@basf.com; Tel.: +1-248-293-7000 \\ 2 Department of Chemical Engineering and Materials Science, Wayne State University, Detroit, MI 48202, USA \\ Academic Editor: Andreas Jossen \\ Received: 12 September 2016; Accepted: 26 September 2016; Published: 2 October 2016
}

\begin{abstract}
Nineteen papers focusing on recent research investigations in the field of nickel/metal hydride (Ni/MH) batteries have been selected for this Special Issue of Batteries. These papers summarize the joint efforts in Ni/MH battery research from BASF, Wayne State University, the National Institute of Standards and Technology, Michigan State University, and FDK during 2015-2016 through reviews of basic operational concepts, previous academic publications, issued US Patent and filed Japan Patent Applications, descriptions of current research results in advanced components and cell constructions, and projections of future works.
\end{abstract}

Keywords: nickel/metal hydride (Ni/MH) battery; rechargeable alkaline battery; metal hydride $(\mathrm{MH})$ alloy; electrochemistry; electrolyte; synergetic effect

\section{Introduction}

Nickel/metal hydride $(\mathrm{Ni} / \mathrm{MH})$ rechargeable batteries are one of the important power sources for various consumer types of mobile applications, stationary energy storage, and, most distinctively, transportation usages. In the consumer market, more than one billion cylindrical cells are built annually to replace highly toxic $\mathrm{Ni}-\mathrm{Cd}$ batteries and throw-away primary alkaline batteries with $\mathrm{Ni} / \mathrm{MH}$ batteries of the same nominal voltage $(1.2 \mathrm{~V})$ and higher energy [1,2]. In stationary applications, $\mathrm{Ni} / \mathrm{MH}$ batteries offer a wide operation/storage temperature range, a high energy density, and a very long service life [3-5]. For propulsion applications, more than 10 million hybrid electrical vehicles currently on the road are powered by Ni/MH batteries [6]. New applications in start-stop types of micro-hybrid electrical vehicles [7], temporary energy storage for train braking [8], ferries [9], and buses [10] are on the horizon.

Although Ni/MH batteries have an excellent track record for high abuse-tolerance and endurable service life, these batteries suffer from a relatively low gravitational energy density when comparing to rival Li-ion batteries [11]. The demand for higher mileage between charges limits the future perspectives of $\mathrm{Ni} / \mathrm{MH}$ batteries in pure battery-powered electrical vehicles. In order to preempt the gap in energy density, ongoing research activities in $\mathrm{Ni} / \mathrm{MH}$ are currently being conducted in the US, China, Japan, and Europe [12]. In this Special Issue of the journal Batteries, nineteen papers from research within the USA have been collected to reflect the current status of research and development in the area of $\mathrm{Ni} / \mathrm{MH}$ batteries.

\section{Contributions}

The selected papers presented in this Special Issue are highlighted in this section. They are mainly from the research work conducted under a United States Department of Energy (DOE)-Advanced Research Projects Agency-Energy granted program (DE-AR0000386) and can be divided into four general categories: reviews on overall programs and Patents in the area (four papers); metal hydride ( $\mathrm{MH}$ ) alloys used as negative electrode active materials in Ni/MH batteries (eight papers); 
electrolyte composition and additives (two papers); and uses of analytic tools to investigate the nature and failure modes of components in $\mathrm{Ni} / \mathrm{MH}$ batteries (five papers).

\subsection{Reviews in Related Work}

In this area, a single paper has been devoted to reviewing the major accomplishments of the Robust Affordable Next Generation Energy Storage System (RANGE) program funded by the DOE [13]; two papers are reviews of Patents, specifically those granted in the US [14] and applied in Japan [15]; and one review of the field of failure analysis of Ni/MH batteries [16]. In the RANGE program, new anodes, cathodes, and electrolytes-together with a new pouch type of cell assembly-were developed to boost the gravitational energy density of $\mathrm{Ni} / \mathrm{MH}$ batteries to $145 \mathrm{Wh} \cdot \mathrm{kg}^{-1}$ on the cell level. The combination of an advanced Si-anode with an extremely high potential capacity (up to $4000 \mathrm{mAh} \cdot \mathrm{g}^{-1}$ ) and an ionic liquid electrolyte has led to a new era of Ni/MH battery development [13]. In the paper reviewing US Patents on the subject of Ni/MH batteries, 350 US Patents were studied, beginning with active materials, to electrode fabrication, cell assembly, system integration, application, and finally recovery and recycling [14]. This paper also gives a brief introduction to the major components used in Ni/MH batteries. Another paper reviewing Japanese Patent Application takes a different approach. Instead of by subject manner, these Patent Applications were categorized by the filing company/institute [15]. Applications from nine top Ni/MH battery manufacturers, five major component suppliers, and three research institutes (all based in Japan) are included, with special emphasis on the evolution of melting/casting apparatuses, fabrication of paste electrode, and cell construction. The last review paper focuses on studies of failure modes and degradation mechanisms of $\mathrm{Ni} / \mathrm{MH}$ batteries [16]. The paper first gives a brief introduction to the structure of $\mathrm{Ni} / \mathrm{MH}$ batteries and the common experimental methods used in failure analysis. It then describes the capacity loss mechanism under various conditions (temperature, rate, and storage duration), and finally, presents methods for improving the cycle stability using six approaches: improvement to cell design, negative and positive electrodes, separator, electrolyte, and other components.

\subsection{Metal Hydride Alloys}

$\mathrm{MH}$ alloys are the active component in the negative electrodes of $\mathrm{Ni} / \mathrm{MH}$ batteries and are capable of reversibly storing hydrogen in an electrochemical environment [17]. MH alloys with suitable metal-bond strengths for room-temperature electrochemical application can be categorized as solid-solution and pseudo-binary inter-metallic alloys, specifically $A_{3} B, A_{2} B, A B, A B_{2}, A_{3}, A_{2} B_{7}$, and $\mathrm{AB}_{5}$, where $\mathrm{A}$ is one or a combination of rare earth, alkaline earth, and light transition metal elements (Ti and $\mathrm{Zr}$ ) and B is from the group of transition metals (mainly Ni) [18]. Comparisons of the general properties [19] and the high-rate potentials [20] of these alloy systems are available. Out of the eight available alloy systems, four are discussed in this Special Issue and are summarized as follows. Modifications of the A-site atom in body-centered-cubic (bcc) solid-solution alloys increases the storage capacity [21]. The effects of the incorporation of $\mathrm{Mg}$ or Ce in the Laves phase-based $\mathrm{AB}_{2} \mathrm{MH}$ alloys are discussed in [22,23], respectively. Formula optimization [24] and A-site substitution [25] in a series of Laves phase-related bcc alloys leads to a MH alloy suitable for electrical vehicle applications (P37 in [13]). TiNi-based AB MH alloys were investigated due to their low raw material costs and because they are free of rare earth elements [19]. Density function theory has also been employed to study the solubility of two ZrNi-based intermetallic alloys [26]. Last but not least, a new concept of using nickel hydroxide as the anode for $\mathrm{Ni}-\mathrm{Ni}$ batteries is discussed [27]. In addition to the eight papers focusing on $\mathrm{MH}$ alloys, the failure mechanisms of a series of Co-substituted $\mathrm{A}_{2} \mathrm{~B}_{7}$ superlattice alloys is discussed [28], and initial research activities focused on an Mg-based AB MH alloy can be found in the paper discussing the contribution of various hydroxides in the electrolyte [29]. 


\subsection{Electrolyte}

Part of the high-rate charge/discharge capabilities in Ni/MH batteries originates from the use of highly conductive alkaline electrolytes (30-35 wt $\% \mathrm{KOH})$. However, the highly corrosive nature of these electrolytes limits the choice of MH alloys. For example, extremely low cycle stabilities have been reported with Mg- [30,31] and V-containing [32] MH alloys. Therefore, studies focused on balancing corrosion and conductivity in the electrolytes were conducted through the choice of hydroxides [29] and salt additives [33]. In addition, the use of ionic liquid to replace alkaline solution as electrolyte was shown to be effective in reducing corrosion, which allowed attempts to develop high-capacity Si-anodes [13].

\subsection{Analytic Methodology}

Many analytic tools have been applied during the research and development of $\mathrm{Ni} / \mathrm{MH}$ batteries. While analytical methods for MH alloy research can be found in one article [34], those involved in the failure analysis are summarized in a paper in this Special Issue [16]. In this Special Issue, the many uses for transmission electron microscopy (TEM) [35], electron backscatter diffraction (EBSD) [36,37], and X-ray energy dispersive spectroscopy (EDS) elemental mapping in a scanning electron microscope (SEM) [28], X-ray diffraction (XRD), and newly developed electrochemical pressure-concentration-temperature (PCT) measurements [38] were demonstrated to be effective for investigations into the microstructures and various mechanisms in electrochemistry and hydrogen gas-solid interactions. TEM results for a Si-doped $\mathrm{AB}_{2} \mathrm{MH}$ alloy [35] revealed a highly catalytic surface/interface microstructure which accounts for the superior low-temperature performance of the alloy and varies greatly from the conventional nano-Ni clusters embedded in surface oxide model $[39,40]$. The alignment in the crystallographic orientations of the constituent phases revealed by the EBSD technique [36,37] confirm the cleanness of the interface, which is therefore capable of generating synergetic effects and boosting the electrochemical performance of the multi-phase $\mathrm{MH}$ alloy systems [25]. A study comparing gaseous phase PCT and electrochemical PCT further distinguishes the synergetic effects in both environments [38]. The last paper exhibits a combination of analytic tools—including inductively coupled plasma, XRD, SEM, and EDS - to study the failure mechanism of $\mathrm{AB}_{5}$ and $\mathrm{A}_{2} \mathrm{~B}_{7} \mathrm{MH}$ alloys after cycling at high temperature in a sealed-cell configuration [28].

\section{Conclusions}

The joint research efforts from BASF-Ovonic and their collaborators (2015-2016) are highlighted here through nineteen papers focused on the area of $\mathrm{Ni} / \mathrm{MH}$ batteries in this Special Issue of Batteries. It has been demonstrated that achieving equalization of the energy density in the pack level between $\mathrm{Ni} / \mathrm{MH}$ and rival Li-ion batteries is possible through the use of advanced components obtained from these studies. Future research will be focused on high-capacity Si-anodes, choice of high-voltages, multi-electron transfer cathodes, and implementation of the pouch cell design with the use of ionic liquid as the electrolyte.

Acknowledgments: The Guest Editor (Kwo-Hsiung Young) thanks both the colleagues who made impressive and important contributions to the articles and the editorial team at the publisher MDPI for rending precious guidance. Kwo-Hsiung Young is also obligated to RoseFigura Jordan at the Rockefeller University for refinement in his writing skill.

Conflicts of Interest: The author declares no conflict of interest.

\section{References}

1. Teraoka, H. NiMH Stationary Energy Storage-Extreme Temperature and Long Life Developments. In Proceedings of the 33rd International Battery Seminar \& Exhibit, Fort Lauderdale, FL, USA, 21-24 March 2016. 
2. HighPower International. The Current Status and Future Trend of Domestic and International Market of Ni/MH Batteries. 2014. Available online: http://cbea.com/u/cms/www/201406/06163842rc01.pdf (accessed on 8 September 2016). (In Chinese)

3. Zelinsky, M.; Koch, J.; Fetcenko, M. Heat Tolerant NiMH Batteries for Stationary Power; Ovonic Battery Company: Rochester Hill, MI, USA, 2010.

4. Zelinsky, M.; Koch, J. Batteries and Heat-A Recipe for Success? Available online: www.battcon.com/Papers Final2013/16-Mike\%20Zelinsky\%20-\%20Batteries\%20and\%20Heat.pdf (accessed on 8 September 2016).

5. Zelinsky, M.; Koch, J. Market Advancement of NiMH Batteries for Stationary Applications. Available online: www.battcon.com/PapersFinal2016/Zelinsky\%20paper\%202016.pdf (accessed on 8 September 2016).

6. Wikipedia. Hybrid Electric Vehicle. Available online: https://en.wikipedia.org/wiki/Hybrid_electric_vehicle (accessed on 8 September 2016).

7. Panasonic. Headquarters News-Panasonic's 12V Ni-MH Energy Recovery Systems in New Idle-Stop Minicars from Nissan and Mitsubishi. 2014. Available online: http://news.panasonic.com/global/press / data/2014/02/en140213-3/en140213-3.html (accessed on 8 September 2016).

8. Kawasaki Heavy Industry. Battery Power System (BPS) for Railways. Available online: http:/ /global.kawasaki. com/en/energy/solutions/battery_energy/applications/bps.html (accessed on 8 September 2016).

9. Green City Ferries. MOVITZ-The World's First Supercharged Electrical Ferry. Available online: http:/ /www.greencityferries.com/boatfleet/movitz/ (accessed on 8 September 2016).

10. Zibo Guoli New Power Source Technology Co., Ltd. Available online: http://www.glxdy.com (accessed on 8 September 2016).

11. Young, K.; Wang, C.; Wang, L.Y.; Strunz, K. Electrical Vehicle Battery Technologies. In Electric Vehicle Integration into Modern Power Network; Garcia-Valle, R., Lopes, J.A.P., Eds.; Springer: New York, NY, USA, 2013.

12. Yartys, V.A. Ti-Zr Based $\mathrm{AB}_{2}$ Alloys for High Power Metal Hydride Batteries. In Proceedings of the 15th International Symposium on Metal-Hydrogen System, Interlaken, Switzerland, 7-12 August 2016.

13. Young, K.; Ng, K.Y.S.; Bendersky, L.A. A technical report of the Robust Affordable Next Generation Energy Storage System-BASF program. Batteries 2016, 2. [CrossRef]

14. Chang, S.; Young, K.; Nei, J.; Fierro, C. Reviews on the U.S. Patents regarding nickel/metal hydride batteries. Batteries 2016, 2. [CrossRef]

15. Ouchi, T.; Young, K.; Moghe, D. Reviews on the Japanese Patent Applications regarding nickel/metal hydride batteries. Batteries 2016, 2. [CrossRef]

16. Young, K.; Yasuoka, S. Capacity degradation mechanisms in nickel/metal hydride batteries. Batteries $2016,2$. [CrossRef]

17. Young, K. Stoichiometry in Inter-Metallic Compounds for Hydrogen Storage Applications. In Stoichiometry and Materials Science: When Numbers Matter; Innocenti, A., Kamarulzaman, N., Eds.; InTech: Rijeka, Croatia, 2012.

18. Young, K. Electrochemical Applications of Metal Hydrides. In Compendium of Hydrogen Energy; Barbir, F., Basile, A., Veziroğlu, T.N., Eds.; Woodhead Publishing Ltd.: Cambridge, UK, 2016; Volume 3, pp. 289-304.

19. Nei, J.; Young, K. Gaseous phase and electrochemical hydrogen storage properties of $\mathrm{Ti}_{50} \mathrm{Zr}_{1} \mathrm{Ni}_{44} X_{5}(X=\mathrm{Ni}$, $\mathrm{Cr}, \mathrm{Mn}, \mathrm{Fe}, \mathrm{Co}$, or $\mathrm{Cu}$ ) for nickel metal hydride battery applications. Batteries 2016, 2. [CrossRef]

20. Young, K.; Nei, J. The current status of hydrogen storage alloy development for electrochemical applications. Materials 2013, 6, 4574-4608. [CrossRef]

21. Young, K.; Ouchi, T.; Huang, B.; Nei, J. Structure, hydrogen storage, and electrochemical properties of body-centered-cubic $\mathrm{Ti}_{40} \mathrm{~V}_{30} \mathrm{Cr}_{15} \mathrm{Mn}_{13} \mathrm{X}_{2}$ alloys ( $\mathrm{X}=\mathrm{B}, \mathrm{Si}, \mathrm{Mn}, \mathrm{Ni}, \mathrm{Zr}, \mathrm{Nb}, \mathrm{Mo}$, and La). Batteries 2015, 1, 74-90. [CrossRef]

22. Chang, S.; Young, K.; Ouchi, T.; Meng, T.; Nei, J.; Wu, X. Studies on incorporation of Mg in Zr-based $\mathrm{AB}_{2}$ metal hydride alloys. Batteries 2016, 2. [CrossRef]

23. Young, K.; Ouchi, T.; Nei, J.; Moghe, D. The importance of rare-earth additions in Zr-based $\mathrm{AB}_{2}$ metal hydride alloys. Batteries 2016, 2. [CrossRef]

24. Young, K.; Wong, D.F.; Nei, J. Effects of vanadium/nickel contents in Laves phase-related body-centered-cubic solid solution metal hydride alloys. Batteries 2015, 1, 34-53. [CrossRef]

25. Young, K.; Ouchi, T.; Meng, T.; Wong, D.F. Studies on the synergetic effects in multi-phase metal hydride alloys. Batteries 2016, 2. [CrossRef] 
26. Wong, D.F.; Young, K.; Ouchi, T.; Ng, K.Y.S. First-principles point defect models for $\mathrm{Zr}_{7} \mathrm{Ni}_{10}$ and $\mathrm{Zr}_{2} \mathrm{Ni}_{7}$ phases. Batteries 2016, 2. [CrossRef]

27. Wang, L.; Young, K.; Shen, H. New type of alkaline rechargeable battery-Ni-Ni battery. Batteries 2016, 2. [CrossRef]

28. Meng, T.; Young, K.; Koch, J.; Ouchi, T.; Yasuoka, S. Failure mechanisms of nickel/metal hydride batteries with cobalt-substituted superlattice hydrogen-absorbing alloy anodes at $50{ }^{\circ} \mathrm{C}$. Batteries 2016, 2. [CrossRef]

29. Nei, J.; Young, K.; Rotarov, D. Studies on MgNi-based metal hydride electrode with aqueous electrolytes composed of various hydroxides. Batteries 2016, 2. [CrossRef]

30. Mu, D.; Hatano, Y.; Abe, T.; Watanabe, K. Degradation kinetics of discharge capacity for amorphous Mg-Ni electrode. J. Alloys Compd. 2002, 334, 232-237. [CrossRef]

31. Liu, J.; Jiao, L.; Yuan, H.; Wang, Y.; Liu, Q. Effect of discharge cut off voltage on cycle life of MgNi-based electrode for rechargeable Ni-MH batteries. J. Alloys Compd. 2005, 403, 270-274. [CrossRef]

32. Yu, X.B.; Wu, Z.; Xia, B.J.; Xu, N.X. A Ti-V-based bcc phase alloy for use as metal hydride electrode with high discharge capacity. J. Chem. Phys. 2004, 121, 987-990. [CrossRef] [PubMed]

33. Yan, S.; Young, K.; Ng, K.Y.S. Effects of salt additives to the $\mathrm{KOH}$ electrolyte used in $\mathrm{Ni} / \mathrm{MH}$ batteries. Batteries 2015, 1, 54-73. [CrossRef]

34. Young, K. Metal Hydride. In Reference Module in Chemistry, Molecular Sciences and Chemical Engineering; Reedijk, J., Ed.; Elsevier: Waltham, MA, USA, 2013.

35. Young, K.; Chao, B.; Nei, J. Microstructures of the activated Si-containing $\mathrm{AB}_{2}$ metal hydride alloy surface by transmission electron microscope. Batteries 2016, 2. [CrossRef]

36. Liu, Y.; Young, K. Microstructure investigation on metal hydride alloys by electron backscatter diffraction technique. Batteries 2016, 2. [CrossRef]

37. Shen, H.-T.; Young, K.-H.; Meng, T.; Bendersky, L.A. Clean grain boundary found in C14/body-center-cubic multi-phase metal hydride alloys. Batteries 2016, 2. [CrossRef]

38. Mosavati, N.; Young, K.; Meng, T.; Ng, K.Y.S. Electrochemical open-circuit voltage and pressureconcentration-temperature isotherm comparison for metal hydride alloys. Batteries 2016, 2. [CrossRef]

39. Young, K.; Huang, B.; Regmi, R.K.; Lawes, G.; Liu, Y. Comparisons of metallic clusters imbedded in the surface oxide of $\mathrm{AB}_{2}, \mathrm{AB}_{5}$, and $\mathrm{A}_{2} \mathrm{~B}_{7}$ alloys. J. Alloys Compd. 2010, 506, 831-840. [CrossRef]

40. Young, K.; Chao, B.; Pawlik, D.; Shen, H. Transmission electron microscope studies in the surface oxide on the La-containing $\mathrm{AB}_{2}$ metal hydride alloy. J. Alloys Compd. 2016, 672, 356-365. [CrossRef]

(C) 2016 by the author; licensee MDPI, Basel, Switzerland. This article is an open access article distributed under the terms and conditions of the Creative Commons Attribution (CC-BY) license (http://creativecommons.org/licenses/by/4.0/). 